\title{
Potential of Sunflower-Legume Intercropping: A Way Forward in Sustainable Production of Sunflower in Temperate Climatic Conditions
}

\author{
Brankica Babec ${ }^{1, *(\mathbb{D})}$, Srđan Šeremešić ${ }^{2} \mathbb{D}$, Nada Hladni $^{1}$, Nemanja Ćuk ${ }^{1}$ (D), Dušan Stanisavljević ${ }^{1}$ and $^{1}$ \\ Miloš Rajković ${ }^{1}$ (D) \\ 1 Institute of Field and Vegetable Crops, Maksima Gorkog 30, 21000 Novi Sad, Serbia; \\ nada.hladni@ifvens.ns.ac.rs (N.H.); nemanja.cuk@ifvcns.ns.ac.rs (N.Ć.); \\ dusan.stanisavljevic@ifvcns.ns.ac.rs (D.S.); milos.rajkovic@ifvcns.ns.ac.rs (M.R.) \\ 2 Faculty of Agriculture, University of Novi Sad, Dositej Obradović Square 8, 21000 Novi Sad, Serbia; \\ srdjan.seremesic@polj.uns.ac.rs \\ * Correspondence: brankica.babec@ifvcns.ns.ac.rs; Tel.: +381-214898326
}

Citation: Babec, B.; Šeremešić, S.; Hladni, N.; Ćuk, N.; Stanisavljević, D.; Rajković, M. Potential of Sunflower-Legume Intercropping: A Way Forward in Sustainable Production of Sunflower in Temperate Climatic Conditions. Agronomy 2021, 11, 2381. https://doi.org/10.3390/ agronomy11122381

Academic Editor: Reinhard W. Neugschwandtne

Received: 8 November 2021

Accepted: 19 November 2021

Published: 24 November 2021

Publisher's Note: MDPI stays neutral with regard to jurisdictional claims in published maps and institutional affiliations.

Copyright: (c) 2021 by the authors. Licensee MDPI, Basel, Switzerland. This article is an open access article distributed under the terms and conditions of the Creative Commons Attribution (CC BY) license (https:/ / creativecommons.org/licenses/by/ $4.0 /)$.
Abstract: The ongoing climate change, coupled with the transformations of cultivation practices and land use in sole crop production, may cause a significant decline in sunflower yield stability. Considering that the sunflower is the third oilseed in the world oilseed market, with 45 million tons of grain per year, and that it takes the fourth position in the vegetable oil market, the implementation of sustainable growing technology in sunflower production is a necessity. Considering the above, the goal of the research was to analyze and recommend sustainable sunflower production technology in intercropping systems. A four-year trial was conducted in Serbia's agroecological conditions $\left(45^{\circ} 34^{\prime} 23.2^{\prime \prime} \mathrm{N} 19^{\circ} 86^{\prime} 18.9^{\prime \prime} \mathrm{E}\right)$ using a split-plot design. Two oil-type hybrids and one confectionarytype hybrid were intercropped with common vetch, red clover, and alfalfa. Common vetch $\times$ sunflower intercropping resulted in the decrease in almost all sunflower traits. Moreover, sunflower $\times$ alfalfa intercropping proved to be the most appropriate. The yield of NS Gricko and Rimi PR were statistically on the same level with sole cropping, while alfalfa biomass had better results after alfalfa was intercropped with NS Gricko, as compared to sole cropping. In view of the prevailing belief that yields are more stable in intercropping than in sole cropping, further research is needed in this respect, in addition to further research of the time and method of sowing.

Keywords: sunflower; intercropping; legumes; sustainable production

\section{Introduction}

Changing climate conditions coupled with the transformations in cultivation practices and land use in sole cropping sunflower (Helianthus annuus L.) production may significantly decline yield stability of this important oilseed crop. More than $80 \%$ of this crop is mainly grown in just 10 world countries, primarily in Ukraine, Russia, and Argentina, and twothirds of the world's production is concentrated in Europe [1]. Considering the global significance of sunflower, it is essential to test the methods of its sustainable production in the times of population growth and accelerated climate change characterized by higher average temperatures, extreme climatic hazards, reduced water availability and water logging, and so forth [2]. Despite the constant improvement of genetic yield potential in the recent years, most of the mentioned sunflower production countries have experienced yield gaps, between 1.1 and $2.4 \mathrm{tha}^{-1}$ at a national level [1]. Along with inadequately performed agro-technical measures, a considerable number of resistant weed species, nutrient uptake inefficiency, drought, poor disease, weed and pest control also affect the reduction of yield. Thus, modification and improvement of cropping practices suitable for the changing climate will have a major role in the achievement of sustainable sunflower production and global food security [3]. 
Diversity at all levels, from genetic to the ecosystem, enhances the ability of cropping systems to overcome and adapt to the forthcoming changes. According to the EU Biodiversity Strategy for 2030, biodiversity is fundamental in preserving the EU and world food safety [4]. Along with food safety, biodiversity supports healthy and nutrient-rich diets, enhances the efficiency of agroecosystems, and boosts resilience to the changing environmental conditions, climate risks and socioeconomic challenges. In addition to the EU Biodiversity Strategy for 2030, the Farm to Fork Strategy, and the new Common Agricultural Policy (CAP) are also encouraging eco-schemes development and sustainable systems implementation.

Many alternative cultivation practices can be applied in order to adapt crop production to climate change and variability. Although it is a centuries-old farming system, intercropping can be considered as one of the solutions for 21st century agriculture, and applied in order to improve resource use efficiency and yield stability. Some of the reasons for intercropping are increased yields of crops by more efficient utilization of soil and rainfall in a growing area, better disease, pest, and weed control, more uniform distribution of labour and saleable produce over a calendar year, greater stability of annual yields compared to sole-cropping, more effective control of erosion, decrease or elimination of the need for commercial fertilizers, reduced risk of crop failure, and many others [5-11].

Intercropping has been widely used in some countries. Over $40 \%$ of maize (Zea mays L.) in the Dominican Republic, 50\% of maize in Jamaica, and 60\% of beans (Phaseolus vulgaris L.) in Brazil is intercropped, while $50 \%$ of the Zimbabwe growing area is cultivated with mixed crops [12]. In Latin America, small-scale farmers grow between 70-90\% of beans intercropped with maize, potatoes (Solanum tuberosum L.), and other crops, whereas maize is intercropped at $60 \%$ of the maize-growing areas [13]. However, in Europe, intercropping disappeared from many systems and currently remains in agroforestry, orchard, or vegetable production. Intercropping is a sporadic growing technology in industrial agriculture and intensive production systems, yet its use is expanding in organic production systems [14].

Research on intercropping has shown that the best combination is when one of the species is from the Fabaceae family. Species from this family are "expected" to be able to create a large aboveground mass, have a strong root system with high absorption capacity, and have moderate nutrition requests, for example, they should be more adaptable to poorer soils and shaded conditions, with high weed suppression and an ability to fix atmospheric nitrogen even in competition conditions, as in intercropping [15-17]. Driven by photosynthesis, biological nitrogen fixation by legumes is a significant ecosystem service, which can partially meet the nitrogen needs of other crops in the system, and improve their overall productivity [18]. According to the Food and Agriculture Organization of the United Nations (FAO), the present global use of $\mathrm{N}$ fertilizer is assessed at around $110 \mathrm{Tg}$ of $\mathrm{N}_{\text {year }}{ }^{-1}$ [19]. The $\mathrm{N}_{2}$ fixed by grain legumes is assessed at around $22 \mathrm{Tg} \mathrm{N}$ and by forage legumes around $20 \mathrm{Tg} \mathrm{N}_{\text {year }}^{-1}$, which is low given the fact that, prior to the mass introduction of $\mathrm{N}$ fertilizers, $25-50 \%$ of agricultural land was commonly cropped on a legume base using cover crops and animal manure [20]. Regarding the effect of main species in intercropping on legumes, it is highly possible that legumes' biomass and biomass-related traits will be affected in the year of the establishment. However, bearing in mind the above-mentioned legume characteristics, after the main crop harvest, legumes usually rapidly regenerate $[16,18,20]$.

With all of the above-mentioned factors in mind, the goal of this research is to:

(i) Analyse and recommend sustainable production technology of sunflowers in intercropping systems. The research considered sunflowers as the main cash crop, and investigated different legumes as complementary crops;

(ii) Define the most suitable legumes for intercropping with sunflowers. The aim is to determine how legumes affect sunflower production, qualitative, physiological and morphological traits; 
(iii) Analyse how this system affects perenniallegumes as crops that remain for exploration in the second year after the sunflower harvest (in the first year).

\section{Materials and Methods}

\subsection{Experimental Design}

For the purpose of our study, a four-year trial was conducted from 2017 to 2020 at the experimental fields of the Institute of Field and Vegetable Crops, Novi Sad, Serbia at Rimski šančevi $\left(45^{\circ} 34^{\prime} 23.2^{\prime \prime} \mathrm{N} 19^{\circ} 86^{\prime} 18.9^{\prime \prime}\right.$ E). Prior to the trial establishment, the selected plot was divided into four parts in order to respect the sunflowers' requirement for crop rotation. Three hybrids of sunflower, two oil types (Rimi PR and Dukat), and one confectionary type (NS Gricko) were intercropped with forage legumes (Vicia sativa L., Novi Beograd variety; Trifolium pratense L., Una variety; Medicago sativa L., Banat vs. variety), whereas sole cropping of sunflower and legumes was used as the control treatment (Figure 1). A rain-fed experiment was established using a split-plot design in four repetitions (Figure 2). All plant varieties were created and produced at the Institute of Field and Vegetable Crops, Novi Sad. The implemented cultivation practices were the same in the production area of the Republic of Serbia, by using mouldboard ploughing at $27-30 \mathrm{~cm}$ soil depth in autumn. Grain sorghum was used as the preceding crop to ensure a neutral impact on the main crop, and legumes as the complementary crop. Mouldboard ploughing ensured sorghum residue incorporation into the soil. Pre-sowing seedbed preparation and cultivation was carried out by the System Kompactor at optimal soil moisture. Sunflower hybrids were sown as the main crop in the first half of April, while legumes, as a supplementary crop, were sown a day before. Sunflower was sown with a Wintersteiger PSP Single Disk seeder in six rows, with a row spacing of $70 \mathrm{~cm}$ and a $25 \mathrm{~cm}$ spacing of plants in a row, and the sowing rate was the same in the sole crop and in intercropping treatments. Legumes were sown with anAmazone 08-30 Super seed drill (seeder). The sowing rate of red clover and alfalfa was $18 \mathrm{~kg} / \mathrm{ha}$ and the common vetch $120 \mathrm{~kg} / \mathrm{ha}$, the same as in biomass production. The sowing rate of the legumes was the same in sole crop and in intercropping treatments, with a row spacing of $12.5 \mathrm{~cm}$. The size of the single plot was $9 \times 3.5 \mathrm{~m}$, with $1.5 \mathrm{~m}$ spacing between treatments, that is, legumes, and repetitions. In the autumn before winter ploughing, basic macronutrients were supplied to the soil in the form of double NP (11:52) fertilizer MAP with high phosphorus content and sufficient amounts of nitrogen, in the amount of $220 \mathrm{~kg} \mathrm{ha}^{-1}$. Before sowing, the soil was rolled to provoke the initial emergence of weeds, which were then destroyed by interrow cultivation. After the emergence of crops, two hand weedings were applied in the row area. After the sunflower harvest, red clover and alfalfa were left for exploitation in the following year.
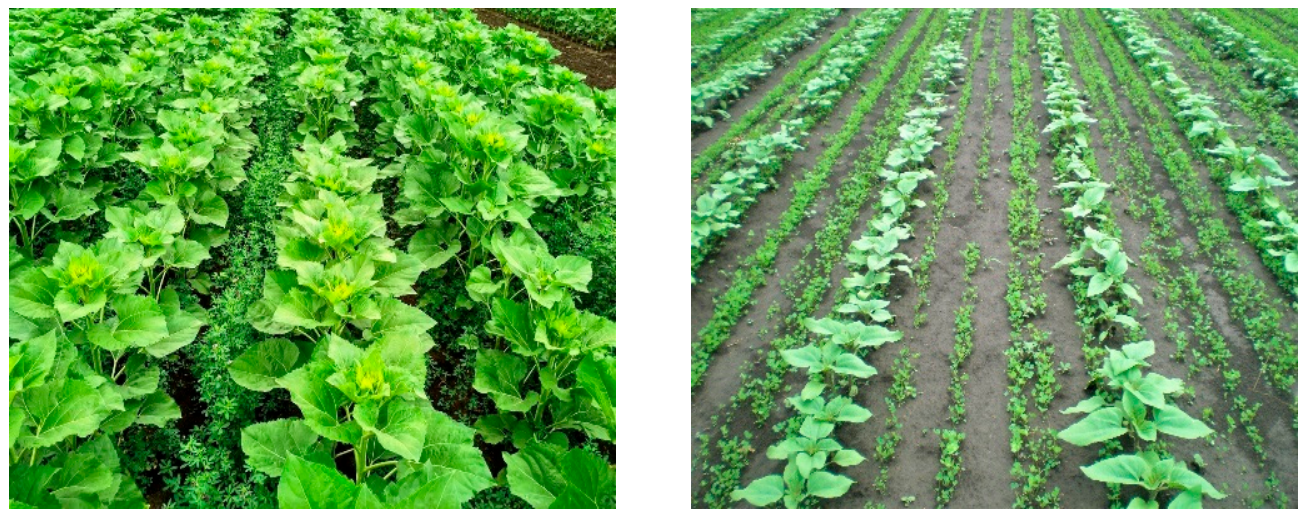

Figure 1. Spatial arrangement of the sunflower legume intercropping (six rows of legumes between two sunflower rows). 


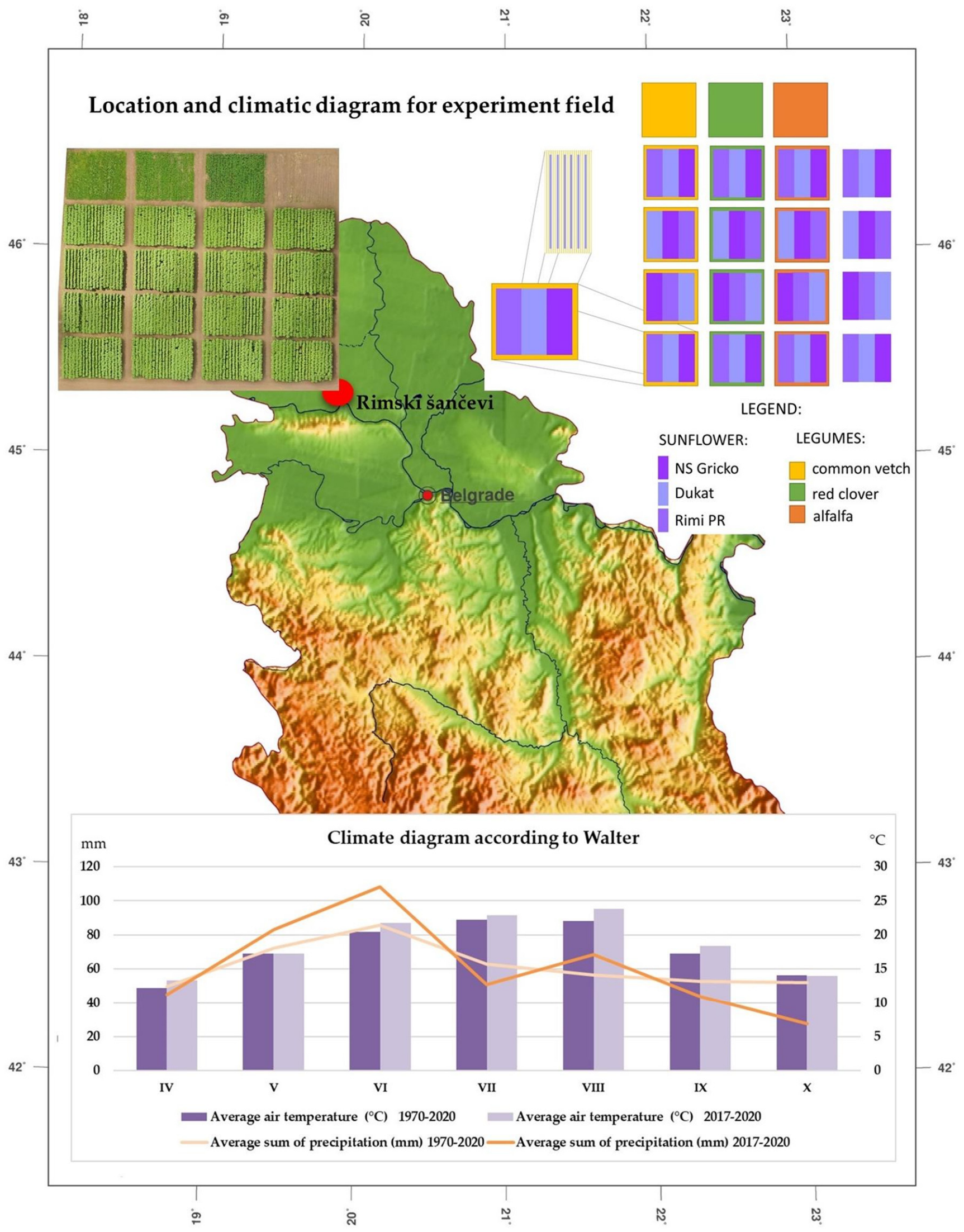

Figure 2. Location of the trial and climatic conditions for the study period with long-term averages. 


\subsection{Field Site Description}

\subsubsection{Location and Weather Conditions}

The field trial area was located in the southern part of the Pannonian plane, where the climate was moderately continental with seasonal variations in temperature and precipitation. Based on the long-term data (1970-2020), the mean annual temperature was $11.7^{\circ} \mathrm{C}$, annual precipitation sum $642.8 \mathrm{~mm}$, the mean temperature for the growing period (AprilOctober) was $17.6^{\circ} \mathrm{C}$, and the precipitation sum for the growing period was $431.7 \mathrm{~mm}$. The mean monthly temperature and monthly precipitation data for the vegetation period from 2017 to 2020 were taken at the Meteorological Station-Rimski šančevi, the Republic Hydrometeorological Service of Serbia, and the data are shown in the Walter climate diagram (Figure 2). In 2017, the precipitation level was $82.9 \mathrm{~mm}$ in May, and $12.0 \mathrm{~mm}$ and $17.4 \mathrm{~mm}$ in July and August, respectively, with extremely high temperatures in these two months. The average temperature during the growing season was $19^{\circ} \mathrm{C}$. About $20 \mathrm{~mm}$ less precipitation was recorded in May 2018 than in 2017, but June was extremely humid with $163.2 \mathrm{~mm}$ of precipitation, which is about $100 \mathrm{~mm}$ more than in 2017. July precipitation was also above the 50-year average $(81.2 \mathrm{~mm})$. The average daily temperature during the 2018 growing season was $19.8^{\circ} \mathrm{C}$. The beginning of the growing period in April was extremely warm with an average daily temperature of $17.2^{\circ} \mathrm{C}$. In 2019 , the highest sum of precipitation was recorded in May, namely, $147.6 \mathrm{~mm}$, whereas July was dry with only $21.00 \mathrm{~mm}$ of rain. Regarding the temperatures, this year was similar to the long-term averages, with May being about 3 degrees colder than average and June about 3 degrees warmer. In 2020, April and October were very dry with just $14.0 \mathrm{~mm}$ and $5.0 \mathrm{~mm}$ of rain, respectively. Regarding the temperatures, 2020 was similar to the long-term averages. The monthly temperature averages in the four-year period of the experiment varied considerably compared to the 50-year average, so it can be concluded that the weather conditions have been fairly variable and unpredictable during the experiment.

\subsubsection{Soil Sampling and Characteristics}

Composite samples were taken in three replicates at adepth of $10-30 \mathrm{~cm}$ at the beginning of each vegetative season. Regarding soil chemical properties, the following were done: active acidity $\left(\mathrm{pH}\right.$ in $\left.\mathrm{H}_{2} \mathrm{O}\right)$ and potential acidity $(\mathrm{pH}$ in $\mathrm{KCl})$ with relation $10 \mathrm{~g}: 25 \mathrm{~cm}^{3}$ of soil and solution; calcium carbonate $\left(\mathrm{CaCO}_{3}\right)$ content (volumetrically, using a Scheiblercalcimeter); organic matter content (oxidation of organic matter by Tyurin method); total nitrogen content (CNS elemental analysis of total combustion), using the CHNS analyzer; readily available phosphorus and potassium (extraction with ammonium lactate- the AL method; spectrophotometrically- $-\mathrm{P}_{2} \mathrm{O}_{5}$, and flame-photometrically- $\mathrm{K}_{2} \mathrm{O}$ ). The mechanical composition represents the content of all mechanical fractions, expressed as the percentage of dry sample mass. Determination of mechanical composition of soil (sievingsedimentation) was done by the pipette method, while preparation of samples was carried out with Na-pyrophosphate according to Thyn. Analyses were performed in the Laboratory for Soil and Agroecology of the Institute of Field and Vegetable Crops, Novi Sad.

According to the FAO/WRB classification [21], the soil in the experimental plots is slightly carbonated loamic chernozem-Calcic Gleyic Chernozem (CH-cc.gl-lo). Before the trial establishment, the analysis showed that $\mathrm{pH}$ in $\mathrm{KCl}$ was 7.05 and in $\mathrm{H}_{2} \mathrm{O}$, 7.94; organic matter was 3.13\% (mas \%); $\mathrm{CaCO} 31.06 \%$ (vol \%); $\mathrm{N}$ total 0.236\% (mas \%); $\mathrm{AL}-\mathrm{K}_{2} \mathrm{O}$ $423 \mathrm{mg} \mathrm{kg}^{-1}$; $\mathrm{AL}-\mathrm{P}_{2} \mathrm{O}_{5} 933 \mathrm{mg} \mathrm{kg}^{-1}$. Based on the results of soil analyses (Table 1), it can be concluded that the $\mathrm{pH}$ reaction of the soil in $\mathrm{KCl}$ is neutral, while in water, it is neutral to alkaline. The soil can be characterized as slightly carbonated. It is moderately provided with humus and total nitrogen, and poorly to moderately provided with readily available phosphorus, and potassium. Table 1 shows values of the above-mentioned soil characteristics before the trial establishment. 
Table 1. Characteristics of the soil before the establishment of the trial.

\begin{tabular}{|c|c|c|c|c|c|c|}
\hline \multicolumn{7}{|c|}{ Soil Chemical Properties } \\
\hline \multicolumn{2}{|c|}{$\mathrm{pH}$} & \multirow{2}{*}{$\mathrm{CaCO}_{3} \%(\mathrm{vol} \%)$} & \multirow{2}{*}{$\mathrm{OM} \%$ (mas \%) } & \multirow{2}{*}{$\begin{array}{l}\text { total } N \% \\
(\text { mas \%) }\end{array}$} & \multirow{2}{*}{$\begin{array}{l}\text { AL- } \mathrm{P}_{2} \mathrm{O}_{5} \\
\mathrm{mg} \mathrm{kg}\end{array}$} & \multirow{2}{*}{$\begin{array}{l}\mathrm{AL}-\mathrm{K}_{2} \mathrm{O} \\
\mathrm{mg} \mathrm{kg}^{-1}\end{array}$} \\
\hline in $\mathrm{KCl}$ & in $\mathrm{H}_{2} \mathrm{O}$ & & & & & \\
\hline 7.05 & 7.94 & 1.06 & 3.13 & 0.236 & 933 & 423 \\
\hline \multicolumn{7}{|c|}{ Soli Texture } \\
\hline \multicolumn{2}{|c|}{$\begin{array}{l}\text { rough sand } \\
(2-0.2 \mathrm{~mm}) \%\end{array}$} & \multicolumn{2}{|c|}{$\begin{array}{c}\text { fine sand } \\
(0.2-0.02 \mathrm{~mm}) \%\end{array}$} & $\begin{array}{c}\text { silt } \\
(0.02-0.002 \mathrm{~mm}) \%\end{array}$ & $\begin{array}{c}\text { clay } \\
(<0.002 \mathrm{~mm}) \%\end{array}$ & $\begin{array}{l}\text { texture class } \\
\text { (Tommerup) }\end{array}$ \\
\hline \multicolumn{2}{|c|}{0.82} & \multicolumn{2}{|c|}{38.12} & 31.30 & 30.31 & loamy clay \\
\hline
\end{tabular}

\subsection{Plant Biometric Assessment}

2.3.1. Yield and Yield-Related Traits in Sunflower

During the four-year period, the yield and yield components of sunflower were analyzed, as well as of the sunflower quality components. The sample size for the field measurement included 10 randomly selected plants per repetition, and 20 plants per repetition were used for laboratory measurements. Two internal rows (excluding the first and the last plant, i.e., every other plant) were used for the analysis of sunflower seed yield (SY) and yield components. Thousand-seed weight (TSW) (g) was measured on a random sample of absolutely clean and air-dried seed by measuring $2 \times 200$ seeds, and converted to 1000 seeds. The number of full seeds per head (NFSH) was counted manually. Seed yield per head (SYH) (g) was measured after manually harvesting the plot at $9 \%$ moisture. The obtained yield per sunflower head was converted into $t \mathrm{ha}^{-1}$ relative to counted number of plants per plots. The analysis of oil content (OC) in the grain was carried out non-destructively on pure air-dried seed samples, in a nuclear magnetic resonance (NMR) analyzer [22] and expressed in $\mathrm{g} 100 \mathrm{~g}^{-1}$. The oil yield (OY), obtained as a product of grain yield and grain oil content, was expressed in $\mathrm{kg} \mathrm{ha}^{-1}$. Samples for the oil content determination were formed according to the ISO 9001 procedure.

In addition to seed and oil yield and yield component analysis, the study accessed plant height $(\mathrm{cm})$ and head diameter (HD) $(\mathrm{cm})$, measuring 10 plants of each hybrid in the four repetitions. The total leaf area of sunflower per plant $\left(\mathrm{cm}^{2}\right)$ was measured using a LI3100 area meter (LI-COR) at the BBCH stage 55 (bud stage) and 63 (flowering stage). The samples were taken from five sampling areas per repetition. The height of the sunflower plants was measured by a graduated bar, at the $\mathrm{BBCH}$ stage 55 and 63 . The head diameter was measured at the flowering stage (BBCH stage 63) using a millimetre strip.

\subsubsection{Biomass and Biomass-Related Traits in Legumes}

During the four-year period, plant biomass and crop height were measured for common vetch, red clover, and alfalfa in the year of the establishment. The number of shoots per plant was also measured in red clover and alfalfa. All measurements' results were collected during the flowering phase of the legumes. The sample size for crop height and number of shoots per plant was 10 plants per repetition at internal rows (excluding the first and last plants). To estimate the plant biomass, three samples per repetition were taken using a $50 \mathrm{~cm}^{2}$ wooden frame. Crop height was measured by a graduated bar, and the number of shoots were measured manually. 


\subsubsection{Land Equivalent Ratio (LER)}

The efficiency of intercropping was assessed by a land-equivalent ratio (LER) [23], defined as the relative land area required for sole crops to produce the same yields as intercrops, at the same management level. Considering that the selected combination of crops included sunflower as an annual, and red clover and alfalfa as perennial species, and that they manifested their full potential after the first year, we modified LER and created the LERmax index. Therefore, the land that was to be used for sole cropping (one year of sunflower and two years of legumes) in the course of three years was used for two years in the intercropping system. LERmax indicated the yield of sunflower in the first, and fresh legume biomass in the second year, and was calculated as follows:

$$
\mathrm{LER} \text { max }=\mathrm{L}(\mathrm{a})+\mathrm{L}(\mathrm{b})=\frac{\mathrm{Y}(\mathrm{a})}{\mathrm{S}(\mathrm{a})}+\frac{\mathrm{Y}(\mathrm{b})}{\mathrm{S}(\mathrm{b})}
$$

where L (a) and L (b) are partial LER indexes for sunflowers in the first year and legumes in the second year from trial establishment, respectively; $Y(a)$ and $Y(b)$-yields of sunflower and legumes in the intercropping, respectively; $\mathrm{S}(\mathrm{a})$ and $\mathrm{S}(\mathrm{b})$-yields of sunflower and legumes in sole cropping, respectively.

If the LERmax value is equal to 1, it does not matter whether the crop is grown in sole cropping or intercropping because productivity remains unchanged. If the LERmax value is 1.1 or 1.3 , for example, intercropping stands out by $10 \%$, namely $30 \%$, or more precisely, $10 \%$; that is, $30 \%$ more land area is needed in sole cropping to gain the same yield obtained as in intercropping.

\subsection{Statistical Analyses}

The linear mixed model (LMM) was fitted to every sunflower and every legume trait according to the model for a split-plot design. Three different legumes were used as the main plot, and sunflower hybrids were used as a sub-plot. Sole cropping of sunflower and legumes was used to compare trait performances of these species in sole and intercropping, as well as for LERmax calculation. All terms related to the main plot and sub-plot were treated as the fixed effects in the model (including various interaction effects), whereas the corresponding errors were related to the fixed effects in the model as the random terms. For every particular trait, two independent models were fitted: (i) A model which assumes the homogeneous residual variances across the years, and (ii) a model which assumes the heterogeneous residual variances across the years. The selection among two competitive models was made according to the Bayesian Information Criterion (BIC). The model with the lowest BIC value was selected for further discussion regarding the statistical inference of fixed model terms and least-squares comparisons. Additional $t$-tests ( $p$ values were adjusted byTukey-Kramer to control type I error) were performed in order to estimate mean differences. The LMM procedure was done in SAS [24]. A linear relationship between sunflower variables (traits) was calculated by Pearson correlation coefficients in SPSS [25].

\section{Results}

\subsection{Yield and Yield-Related Traits in Sunflower}

Yield is considered the most important among sunflower production indices; however, the potential of intercropping can be revealed by access to various morphological properties. Two different models were used based on BIC statistics as penalized-likelihood criteria. For the following traits, head diameter, oil content, plant height in bud phase (PHB), plant height in flowering (PHF), total leaf area per plant in flowering (TLAF) and thousand seed weight, a more suitable model (Model 1) was with the homogeneous residual error variances across the years, while for the number of full seeds per head, seed yield, oil yield, seed yield per head, and total leaf area per plant in bud phase (TLAB), the more suitable model (Model 2) was with the heterogeneous residual error variances across the years (Table 2). 
Table 2. Bayesian Information Criteria statistics for Model 1 and 2.

\begin{tabular}{lcc}
\hline Trait & Model 1 & Model 2 \\
\hline plant height/bud phase (PHB) & $\mathbf{7 0 7 . 4}$ & 718.6 \\
plant height/flower phase (PHF) & $\mathbf{7 1 7 . 8}$ & 732.7 \\
head diameter (HD) & $\mathbf{3 8 0 . 5}$ & 393.8 \\
total leaf area/bud phase (TLAB) & 1549.3 & $\mathbf{1 5 2 5 . 5}$ \\
total leaf area/flower phase (TLAF) & $\mathbf{1 5 7 9 . 5}$ & 1594.5 \\
number of full seeds per head (NFSH) & 1304.9 & $\mathbf{1 2 8 6 . 3}$ \\
thousand-seed weight (TSW) & $\mathbf{6 7 0 . 7}$ & 681.2 \\
seed yield per head (SYH) & 782.2 & $\mathbf{7 8 1 . 1}$ \\
seed yield (SY) & $\mathbf{1 6 8 . 2}$ & 163.5 \\
oil content (OC) & $\mathbf{3 8 9 . 5}$ & 401.8 \\
oil yield (OY) & 14.5 & $\mathbf{1 1 . 7}$ \\
\hline
\end{tabular}

Table 3 shows LMM analyses for all sunflower traits and indicates high statistical significance for different types of cropping (legumes and sole cropping), hybrids, and types of cropping $\times$ hybrid interaction, so additional tests were performed.

Additional $t$-tests ( $p$ values were adjusted byTukey-Kramer to control type I error) shown in Table 4 indicate a clear interaction between intercrops and control. Analyzed combinations showed high variability in sunflower HD, which is to be expected considering that three hybrids of different purposes were tested (short vegetation oil type hybrid, Clearfield oil type hybrid, confectionary type hybrid). NS Gricko $\times$ common vetch had the smallest statistically significant HD $(16.50 \mathrm{~cm})$, and the highest when intercropped with alfalfa (19.68), but not significant compared to the control (18.98 cm). Hybrid Dukat had the same trend; Dukat $\times$ common vetch $18.71 \mathrm{~cm}$, Dukat in sole cropping $21.91 \mathrm{~cm}$. Hybrid Rimi PR had the smallest HD $(16.77 \mathrm{~cm})$ when intercropped with common vetch, but was significantly different only compared to the control $(18.55 \mathrm{~cm})$; Rimi PR in red clover alfalfa and control were on the same level of significance. OC was not significantly different in any legume intercrop regarding all tree hybrids. It was insignificantly the highest in the sole crop of sunflower, and usually the lowest in intercropping sunflower hybrids with common vetch. The plant height of sunflowers was analyzed in the bud (PHB) and flower phase (PHF), and clear growth progression was observed in all three hybrids. In hybrid NS Gricko PHB and PHF were significantly the lowest when intercropped with common vetch (143.84 and $205.66 \mathrm{~cm}$, respectively), and significantly the highest in sole cropping (169.01 and 231.50, respectively). No significant difference was observed between sole cropping and intercropping with red clover. In hybrid Dukat, PHB and PHF were also significantly the lowest when intercropped with common vetch (125.50 and 155.25 , respectively), but there were no statistically significant differences between intercropping with red clover, alfalfa, and sole cropping, although PHB and PHF were the highest in sole cropping (136.11 and 167.98, respectively). Hybrid Rimi PR had the same trend as Dukat regarding PHB and PHF. The only statistical significance was observed between Rimi PR $\times$ common vetch and all other treatments. As one of the most important traits, SY varied depending on the hybrids rather than the treatments. Hybrid NS Gricko had the lowest SY that was statistically significant when intercropped with common vetch $\left(3.59 \mathrm{t} \mathrm{ha}^{-1}\right)$, and the highestSY, thoughnot significant compared to the other two legumes, in sole cropping $\left(4.93 \mathrm{t} \mathrm{ha}^{-1}\right)$. Hybrid Dukat and NS Gricko showed a similar trend regarding SY. Significantly lower SY was observed in intercropping with common vetch $\left(2.31 \mathrm{t} \mathrm{ha}^{-1}\right)$ compared to the other three treatments, but SY in sole cropping was significantly higher than in intercropping $\left(3.55 \mathrm{t} \mathrm{ha}^{-1}\right)$. Clearfield hybrid Rimi PR had SY $\left(2.77 \mathrm{t} \mathrm{ha}^{-1}\right)$ intercropped with common vetch, which was significantly lower than in other treatments. The same hybrid intercropped with alfalfa had SY of $3.47 \mathrm{t} \mathrm{ha}^{-1}$, which was not significantly lower than the sole crop $\left(4.05 \mathrm{t} \mathrm{ha}^{-1}\right)$, but not significantly higher compared to Rimi PR $\times$ red clover $\left(3.65 \mathrm{tha}^{-1}\right)$. TLAF of NS Gricko was statistically the lowest when intercropped with common vetch $\left(3070.79 \mathrm{~cm}^{2}\right)$ and the highest in sole cropping $\left(5024.42 \mathrm{~cm}^{2}\right)$. The same trait measured for hybrid Dukat was statistically different in 
all treatments; the lowest in intercropping with common vetch and the highest in sole cropping (4661.62, 6634.81, respectively). Performances regarding TLAF in Rimi PR hybrid were the same as with the NS Gricko. Different treatments had no significant effect on TSW in any of the all three hybrids. This trait was significantly higher for NS Gricko in all treatments compared the other two hybrids. NFSH is the first trait better described by Model 2. Intercropping of all three of these hybrids with common vetch significantly reduced NFSH (775, 1106 and 1269, respectively) compared to other treatments. Hybrids NS Gricko and Rimi PR had the highest NFSH in sole cropping, but not significantly higher than red clover and alfalfa intercrops (997 and 1824, respectively). Hybrid Dukat had significantly higher NFSH in sole cropping (1618) than in all three intercrops. The trait that results from seed yield and oil content in hybrid is OY and, while the OC is under a low influence of environmental conditions, it is a fact that OY performs the same as SY. As in SY, intercropping of all three hybrids with common vetch significantly reduced OY compared to the other treatments, to $1.30,1.07$, and $1.17 \mathrm{t} \mathrm{ha}^{-1}$, respectively. Hybrid NS Gricko had the highest OY in sole cropping $\left(1.81 \mathrm{t} \mathrm{ha}^{-1}\right)$ but not significantly compared to red clover and alfalfa intercropping (1.68 and $\left.1.64 \mathrm{t} \mathrm{ha}^{-1}\right)$. Dukat had significantly higher OY in sole cropping than in other treatments $\left(1.64 \mathrm{t} \mathrm{ha}^{-1}\right)$, whereas Rimi PR had the best performance regarding OY in sole cropping and intercropping with alfalfa (1.73 and 1.57, respectively). SYH can explain the influence of legumes on sunflower hybrids. Intercropping of legumes with NS Gricko and Dukat significantly lowered SYH, except in NS Gricko $\times$ red clover combination. Hybrid Rimi PR showed different performances in intercropping. Even though SYH was the highest in sole cropping (100.64 gr), it was not statistically higher than in intercropping with red clover and alfalfa (91.16 and $93.53 \mathrm{gr}$, respectively). The same results of TLAB were obtained in all three hybrids. Intercropping of sunflower with common vetch resulted in the lowest values of TLAB, while sole cropping had statistically the highest values of TLAB. The interaction of all three hybrids with red clover and alfalfa was at the same level of significance.

Table 3. Test of fixed effects for LMM analyses for sunflower traits analyzed in sunflower legumes intercropping.

\begin{tabular}{|c|c|c|c|c|c|c|c|c|c|c|c|}
\hline $\begin{array}{l}\text { Source of } \\
\text { Variation }\end{array}$ & РHB & PHF & HD & TLAB & TLAF & NFSH & TSW & SYH & SY & OC & OY \\
\hline year & $693.91^{* *}$ & $61.99 * *$ & $2.83 *$ & $61.15^{* *}$ & $66.56^{* *}$ & $73.39 * *$ & $41.15^{* *}$ & $5.56^{*}$ & $6.07^{*}$ & $111.45^{* *}$ & $15.55^{* *}$ \\
\hline $\begin{array}{c}\text { type of } \\
\text { cropping }\end{array}$ & $100.21^{* *}$ & $103.82 * *$ & $64.13^{* *}$ & $137.15^{* *}$ & $100.82 * *$ & $95.44^{* *}$ & $1.75^{\mathrm{ns}}$ & $111.39^{* *}$ & $116.77^{* *}$ & $5.73 *$ & $103.43 * *$ \\
\hline hybrid & $873.88^{* *}$ & $1828.98^{* *}$ & $173.77^{* *}$ & $572.70 * *$ & $624.12 * *$ & $510.37^{* *}$ & $4426.96^{* *}$ & $336.86^{* *}$ & $311.99 * *$ & $1478.75^{* *}$ & $43.03 * *$ \\
\hline $\begin{array}{l}\text { year } \times \text { type } \\
\text { of cropping }\end{array}$ & $23.47^{* *}$ & $20.10^{* *}$ & $10.15^{\mathrm{ns}}$ & $2.60 *$ & $1.73^{\mathrm{ns}}$ & $4.62 * *$ & $1.36^{\mathrm{ns}}$ & 5.57 ** & $5.07^{* *}$ & $4.07^{*}$ & $5.96^{* *}$ \\
\hline $\begin{array}{l}\text { year } \times \\
\text { hybrid }\end{array}$ & $253.97 * *$ & $68.87^{* *}$ & $22.76^{* *}$ & $173.15^{* *}$ & $67.43 * *$ & $13.99 * *$ & $6.02 * *$ & $9.56 * *$ & $10.81^{* *}$ & $23.01 * *$ & $12.26^{* *}$ \\
\hline $\begin{array}{c}\text { type of } \\
\text { cropping } \times \\
\text { hybrid }\end{array}$ & $5.37 * *$ & $5.10 * *$ & $4.85^{*}$ & 0.79 ns & $2.51 *$ & $6.98 * *$ & $0.67^{\mathrm{ns}}$ & $1.59^{\mathrm{ns}}$ & $2.16^{\mathrm{ns}}$ & $2.48^{*}$ & $1.21 \mathrm{~ns}$ \\
\hline $\begin{array}{c}\text { year } \times \text { type } \\
\text { of cropping } \\
\times \text { hybrid }\end{array}$ & $6.65^{* *}$ & $6.59 * *$ & $1.29 \mathrm{~ns}$ & $1.11^{\mathrm{ns}}$ & $1.69^{\mathrm{ns}}$ & $1.72^{\mathrm{ns}}$ & $1.63^{\mathrm{ns}}$ & $2.48 *$ & $2.37 *$ & $1.55^{\mathrm{ns}}$ & $1.87^{*}$ \\
\hline
\end{tabular}

PHB—Plant height/bud phase, PHF-Plant heigh/flower phase, HD—Head diameter, TLAB—Total leaf area/bud phase, TLAF-Total leaf area/flower phase, NFSH—Number of full seeds per head, TSW-Thousand seed weight, SYH—Seed yield per head, SY-Seed yield, OC—Oil content, OY-Oil yield; * and ${ }^{* *}$ indicated significant differences were found at $p=0.05$ and 0.001 , respectively; ${ }^{\text {ns }}$ not significant; values from the models selected on the basis of Table 2 .

The correlation of sunflower traits (average of all three hybrids) and different intercrops were visualized by the heat maps in order to elucidate these in a simple and understandable way (Figure 3). The correlation threshold for 95\% (0.05) significance is 0.576 , and for $99 \%$ (0.001) significance is 0.708 . A significant positive correlation was found between SY and SYH in all three types of intercropping and control. Additionally, SYH and SY were positively correlated with OY to a greater extent in all three types of intercrops compared to the control. TLAF and TLAB were also positively correlated but to a greater extent in sunflower $\times$ common vetch interaction compared to other intercrops and the control. PHB and PHF positive correlation was most pronounced in the control (sunflower sole cropping). PHF and OY were in a significant positive correlation in sunflower $\times$ red 
clover and alfalfa intercrops, but not in sunflower $\times$ common vetch and the control. HD and OY were significantly positive correlated only in the sunflower $\times$ alfalfa intercrop. TSW and OY had a significant positive correlation in all three types of intercrops but not in the control. FSH and SYH showed a significant positive correlation with PHB in sunflower $\times$ common vetch intercrops. OY and OC had a significantly negative correlation in sunflower $\times$ red clover and alfalfa intercrops, but not in the control or sunflower $\times$ common vetch intercrops. HD did not have a significant negative correlation with PHB and PHF only in sunflower $\times$ common vetch intercrops. TSW had a significant negative correlation with TLAB, TLAF, and FSH in all three types of intercropping and control. TSW, $\mathrm{SYH}$, and SY also hada significant negative correlation with OC, but the least pronounced correlation was found in sunflower $\times$ common vetch intercrops.

\subsection{Biomass and Biomass-Related Traits in Legumes}

In order to establish how different sunflower hybrids influences each legume, two different models were used based on BIC statistics as penalized-likelihood criteria. Sunflower hybrids and sole cropping of legumes (control) were considered as the type of cropping affecting legume traits. The model with the homogeneous residual error variances across the years (Model 1) was more suitable for crop height, while for total aboveground biomass (fresh) and the number of shots per plant, the more suitable model (Model 2) was the one with the heterogeneous residual error variances across the years (Table 5).

Table 6 shows LMM analyses for all three legume traits and indicates statistical significances regarding year, legume, hybrid and year $\times$ legume, year $\times$ type of cropping, type of cropping $\times$ legume, year $\times$ type of cropping $\times$ legume interactions for total aboveground biomass (fresh) and crop height. Regarding the number of shoots per plant, statistical significance wasfound for different legumes and types of cropping.

Considering the observed statistical significances, additional $t$-tests (corrected with Tukey-Kramer to control type I error) were performed in order to estimate how each hybrid affected legume traits. Additional tests in Table 7 show a clear interaction between intercrops and control. The total aboveground biomass of common vetch and red clover was at the same level of significance in sole crops and in interaction with theRimi PR hybrid. Regarding the total aboveground biomass of alfalfa, interaction with NS Gricko was at the same level of significance in sole cropping. Legume crop height and number of shoots per plant were significantly lowered by all three hybrids.

\subsection{Indicators of Intercropping Competition and Efficiency}

As mentioned, the LERmax value indicates the yield of sunflower in the first, and fresh legume biomass in the second year. Regarding all three hybrids, the study showed that LERmax for both sunflower $\times$ red clover and sunflower $\times$ alfalfa intercropping was greater than 1 (Figure 4), which indicates an advantage in utilizing land resources by this type of intercropping system relative to the corresponding sole crops. The higher average LERmax values were obtained in hybrids NS Gricko and Rimi PR intercropped with red clover (1.6), resulting in a positive impact on land and a clear yield advantage. More precisely, $60 \%$ more land area is needed in sole cropping to gain the same yield obtained as in NS Gricko and Rimi PR $\times$ red clover intercropping. The lowest average LER max values were obtained in Dukat $\times$ alfalfa intercropping (1.4), indicating that at a $40 \%$ larger area is needed for the same yields to be obtained in sole cropping. Comparing the years of study, the highest LERmax values were achieved in 2019/2020. 
Table 4. Least-square means difference for sunflower traits analyzed by the selected model in sunflower legume intercropping.

\begin{tabular}{|c|c|c|c|c|}
\hline Trait & Intercrop & NS Gricko & Dukat & Rimi PR \\
\hline \multirow{4}{*}{$\mathrm{HD}(\mathrm{cm})$} & common vetch & $16.50^{\mathrm{Aa}}$ & $18.71 \mathrm{Ba}$ & $16.77 \mathrm{Aa}$ \\
\hline & red clover & $19.23 \mathrm{Ab}$ & $21.60^{\mathrm{Bb}}$ & $17.75 \mathrm{Cab}$ \\
\hline & alfalfa & $19.68^{\mathrm{Ab}}$ & $21.82 \mathrm{Bb}$ & $17.83^{\mathrm{Cab}}$ \\
\hline & control & $18.98^{\mathrm{Ab}}$ & $21.91 \mathrm{Bb}$ & $18.55^{\mathrm{Ab}}$ \\
\hline \multirow{4}{*}{$\mathrm{OC}\left(\mathrm{g} 100 \mathrm{~g}^{-1}\right)$} & common vetch & $36.34 \mathrm{Aa}$ & $46.88^{\mathrm{Ba}}$ & $41.96 \mathrm{Ca}$ \\
\hline & red clover & $36.64 \mathrm{Aa}$ & $47.03 \mathrm{Ba}$ & $41.49 \mathrm{Ca}$ \\
\hline & alfalfa & $36.38 \mathrm{Aa}$ & $47.26^{\mathrm{Ba}}$ & $40.09 \mathrm{Ca}$ \\
\hline & control & $36.70^{\mathrm{Aa}}$ & 47.51 Ва & $42.51 \mathrm{Ca}$ \\
\hline \multirow{4}{*}{ PHB (cm) } & common vetch & $143.84^{\mathrm{Aa}}$ & $125.50^{\mathrm{Ba}}$ & $161.30^{\mathrm{Ca}}$ \\
\hline & red clover & $163.63 \mathrm{Abc}$ & $134.84^{\mathrm{Bb}}$ & $179.72 \mathrm{Cb}$ \\
\hline & alfalfa & $160.49 \mathrm{Ab}$ & $135.99 \mathrm{Bb}$ & $177.61^{\mathrm{Cb}}$ \\
\hline & control & $169.01 \mathrm{Ac}$ & $136.11^{\mathrm{Bb}}$ & $179.68^{\mathrm{Cb}}$ \\
\hline \multirow{4}{*}{ PHF (cm) } & common vetch & $205.66^{\mathrm{Aa}}$ & $155.25^{\mathrm{Ba}}$ & $202.30 \mathrm{Aa}$ \\
\hline & red clover & $225.53 \mathrm{Abc}$ & $165.71^{\mathrm{Bb}}$ & $222.41^{\mathrm{Ab}}$ \\
\hline & alfalfa & $220.01 \mathrm{Ab}$ & $165.51^{\mathrm{Bb}}$ & $221.34 \mathrm{Ab}$ \\
\hline & control & 231.50 Ac & $167.98^{\mathrm{Bb}}$ & $223.33^{\mathrm{Cb}}$ \\
\hline \multirow{4}{*}{$S Y\left(\right.$ t ha $\left.^{-1}\right)$} & common vetch & $3.59 \mathrm{Aa}$ & $2.31 \mathrm{Ba}$ & $2.77 \mathrm{Ca}$ \\
\hline & red clover & $4.58^{\mathrm{Ab}}$ & $2.91^{\mathrm{Bb}}$ & $3.65 \mathrm{Cb}$ \\
\hline & alfalfa & $4.57 \mathrm{Ab}$ & $2.83^{\mathrm{Bb}}$ & $3.74 \mathrm{Cbc}$ \\
\hline & control & $4.93 \mathrm{Ab}$ & $3.55^{C c}$ & $4.05^{\mathrm{Cc}}$ \\
\hline \multirow{4}{*}{$\operatorname{TLAF}\left(\mathrm{cm}^{2}\right)$} & common vetch & $3070.79 \mathrm{Aa}$ & $4661.62 \mathrm{Ba}$ & $6574.56 \mathrm{Ca}$ \\
\hline & red clover & 4560.81 Аа & $5407.54^{\mathrm{Bb}}$ & $7709.15^{\mathrm{Cb}}$ \\
\hline & alfalfa & $4217.81^{\mathrm{Ab}}$ & $5890.04^{\mathrm{Bc}}$ & $7596.71^{\mathrm{Cb}}$ \\
\hline & control & $5024.42^{\mathrm{Ac}}$ & $6634.81 \mathrm{Bd}$ & $8264.15^{C c}$ \\
\hline \multirow{4}{*}{ TSW (g) } & common vetch & $119.26^{\mathrm{Aa}}$ & $53.01 \mathrm{Ba}$ & $54.22 \mathrm{Ba}$ \\
\hline & red clover & 120.99 Аа & $51.52 \mathrm{Ba}$ & $55.17 \mathrm{Ba}$ \\
\hline & alfalfa & $121.87 \mathrm{Aa}$ & $53.27 \mathrm{Ba}$ & $53.30 \mathrm{Ba}$ \\
\hline & control & 123.51 Аа & $53.50 \mathrm{Ba}$ & $55.42 \mathrm{Ba}$ \\
\hline \multirow{4}{*}{ NFSH (number) } & common vetch & $775^{\mathrm{Aa}}$ & $1106^{\mathrm{Ba}}$ & $1269 \mathrm{Ca}$ \\
\hline & red clover & $940^{\mathrm{Ab}}$ & $1370^{\mathrm{Bb}}$ & $1700 \mathrm{Cb}$ \\
\hline & alfalfa & $924^{\mathrm{Ab}}$ & $1378^{\mathrm{Bb}}$ & $1683^{\mathrm{Cb}}$ \\
\hline & control & $997 \mathrm{Ab}$ & $1618^{\mathrm{Bc}}$ & $1824^{\mathrm{Cb}}$ \\
\hline \multirow{4}{*}{$\mathrm{OY}\left(\mathrm{kg} \mathrm{ha}{ }^{-1}\right)$} & common vetch & $1.30^{\mathrm{Aa}}$ & $1.07^{\mathrm{Ba}}$ & $1.17^{\mathrm{ABa}}$ \\
\hline & red clover & $1.68^{\mathrm{Ab}}$ & $1.37 \mathrm{Bb}$ & $1.51 \mathrm{Ab}$ \\
\hline & alfalfa & $1.64^{\mathrm{Ab}}$ & $1.34^{\mathrm{Bb}}$ & $1.57 \mathrm{ABc}$ \\
\hline & control & $1.81^{\mathrm{Ab}}$ & $1.64^{\mathrm{Ac}}$ & $1.73^{\mathrm{Ac}}$ \\
\hline \multirow{4}{*}{ SYH (g) } & common vetch & $90.22^{\mathrm{Aa}}$ & $57.84^{\mathrm{Ba}}$ & $69.34 \mathrm{Ca}$ \\
\hline & red clover & $114.46^{\mathrm{Abc}}$ & $72.81^{\mathrm{Bb}}$ & $91.16^{\mathrm{Cb}}$ \\
\hline & alfalfa & $112.59 \mathrm{Ab}$ & $71.38^{\mathrm{Bb}}$ & $93.53 \mathrm{Cb}$ \\
\hline & control & $123.14^{\mathrm{Ac}}$ & $85.00^{\mathrm{Bc}}$ & 100. $46^{\mathrm{Cb}}$ \\
\hline \multirow{4}{*}{$\operatorname{TLAB}\left(\mathrm{cm}^{2}\right)$} & common vetch & $3127.81^{\mathrm{Aa}}$ & $5135.06^{\mathrm{Ba}}$ & $5845.54 \mathrm{Ca}$ \\
\hline & red clover & $4299.48^{\mathrm{Ab}}$ & $6129.38^{\mathrm{Bb}}$ & $6983.31 \mathrm{Cb}$ \\
\hline & alfalfa & $4248.19 \mathrm{Aa}$ & $6289.92 \mathrm{Bb}$ & $6802.96^{\mathrm{Bb}}$ \\
\hline & control & $5062.58 \mathrm{Ab}$ & 7123.08 Bc & $7541.52 \mathrm{Bc}$ \\
\hline
\end{tabular}

HD_Head diameter, OC-Oil content, PHB_-Plant height/bud phase, PHF_Plant heigh/flower phase, SYSeed yield, TLAF-Total leaf area/flower phase, TSW-Thousand seed weight, NFSH-Number of full seeds per head, OY-Oil yield, SYH—Seed yield per head, TLAB—-Total leaf area/bud phase; capital letters in superscript denote differences between hybrids; small letters in superscript denote differences between legumes. 
(a)

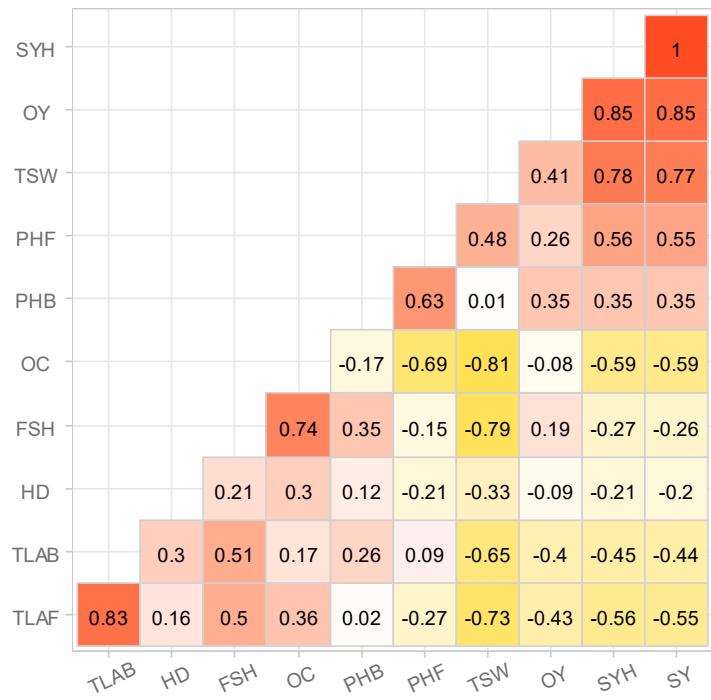

(c)

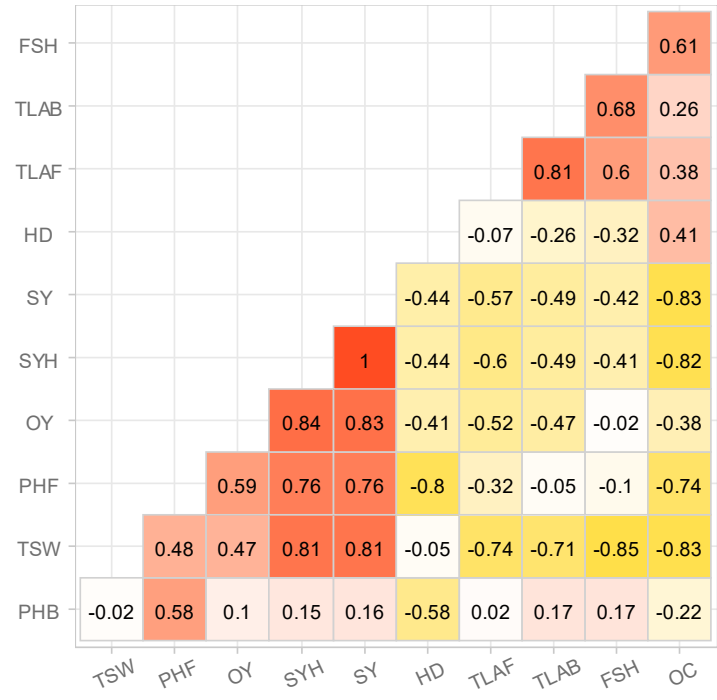

(b)

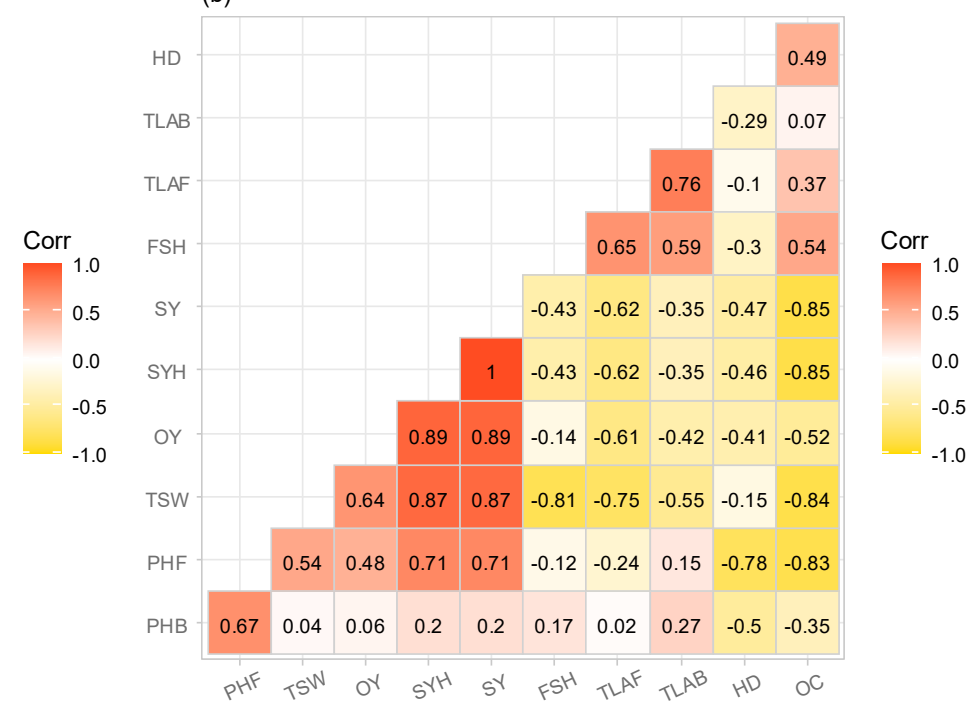

(d)

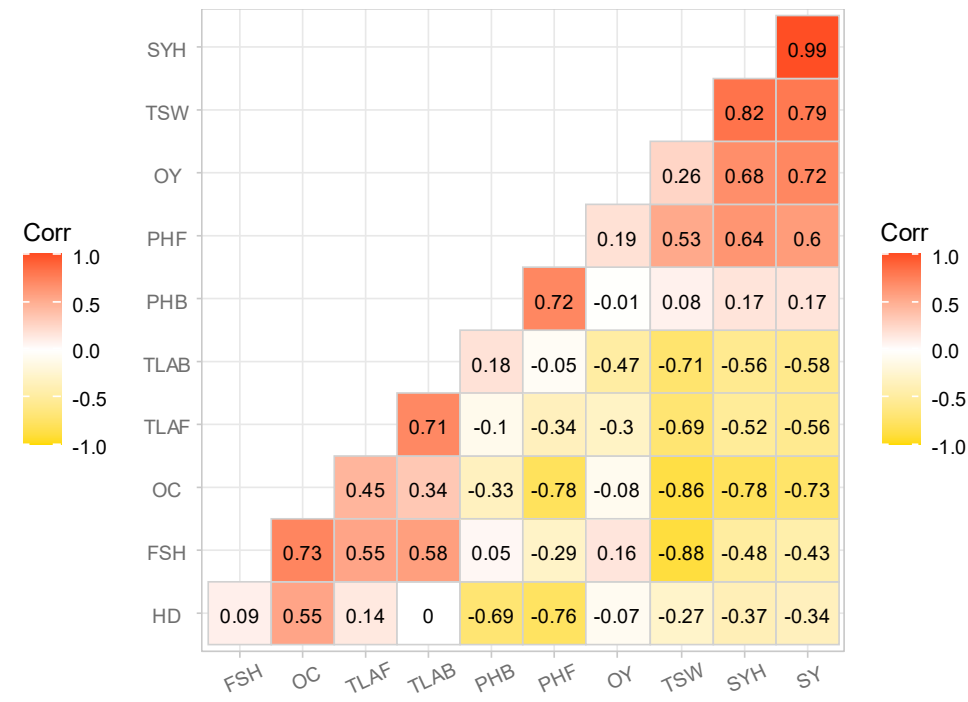

Figure 3. Heat map of sunflower trait correlations (average of all three hybrids); correlation thresholds: $0.05=0.576,0.001$ $=0.708$; (a) sunflower $\times$ common vetch intercrop; (b) sunflower $\times$ red clover intercrop; (c) sunflower $\times$ alfalfa intercrop; (d) sunflower sole cropping; the magnitude of the correlation is denoted with a colour, whereby red indicates a positive correlation and yellow denotes a negative correlation. The stronger the correlation, the darker is the colour; HD-head diameter; OC-oil content; PHB-plant height in bud phase; PHF-plant height in flowering; SY-seed yield; TLAF-total leaf area per plant in flowering; TSW-thousand seed weight; NFSH-number of full seeds per head; OY-oil yield; SYH-seed yield per head; TLAB-total leaf area per plant in the bud phase.

Table 5. Bayesian Information Criteria statistics for Model 1 and 2.

\begin{tabular}{lcc}
\hline Trait & Model 1 & Model 2 \\
\hline total aboveground biomass (fresh) & 899.2 & $\mathbf{8 8 8 . 7}$ \\
crop height & $\mathbf{5 2 9 . 8}$ & 530.0 \\
shoots per plant & 168.4 & $\mathbf{1 5 5 . 4}$ \\
\hline
\end{tabular}


Table 6. Test of fixed effects for LMM analyses for legumes traits analyzed in sunflower legumes intercropping.

\begin{tabular}{lccc}
\hline Source of variation & $\begin{array}{c}\text { Total Aboveground } \\
\text { Biomass (Fresh) }\end{array}$ & Crop Height & Shoots Per Plant \\
\hline year & $33.60^{* *}$ & $71.20^{* *}$ & $2.26^{\mathrm{ns}}$ \\
legume & $40.84^{* *}$ & $233.97^{* *}$ & $709.32^{* *}$ \\
type of cropping & $44.28^{* *}$ & $223.87^{* *}$ & $62.36^{* *}$ \\
year $\times$ legume & $17.01^{* *}$ & $3.78^{*}$ & $1.15^{\mathrm{ns}}$ \\
year $\times$ type of cropping & $1.41^{\mathrm{ns}}$ & $0.95^{\mathrm{ns}}$ & $1.57^{\mathrm{ns}}$ \\
type of cropping $\times$ legume & $4.81^{*}$ & $3.64^{*}$ & $2.06^{\mathrm{ns}}$ \\
year $\times$ type of cropping $\times$ legume & $1.10^{*}$ & $4.96^{* *}$ & $0.30^{\mathrm{ns}}$ \\
\hline *and ${ }^{* *}$ indicated significant differences were found at $p=0.05$ and 0.001, respectively; ${ }^{\text {ns }}$-not significant; values \\
from the models selected on the basis of Table 5.
\end{tabular}

Table 7. Least-square means difference for legume traits analyzed by selected models in sunflower legume intercropping.

\begin{tabular}{ccccc}
\hline Trait & Type of Cropping & Common Vetch & Red Clover & Alfalfa \\
\hline & NS Gricko & $245.69^{\mathrm{a}}$ & $321.01^{\mathrm{a}}$ & $280.62^{\mathrm{bc}}$ \\
total aboveground & Dukat & $269.56^{\mathrm{a}}$ & $306.48^{\mathrm{a}}$ & $245.95^{\mathrm{ab}}$ \\
biomass (fresh) & Rimi PR & $297.42^{\mathrm{ab}}$ & $335.09^{\mathrm{ab}}$ & $223.07^{\mathrm{a}}$ \\
& control & $370.51^{\mathrm{b}}$ & $394.77^{\mathrm{b}}$ & $328.80^{\mathrm{c}}$ \\
\hline \multirow{3}{*}{ crop height } & NS Gricko & $45.0^{\mathrm{a}}$ & $31.5^{\mathrm{a}}$ & $45.5^{\mathrm{a}}$ \\
& Dukat & $54.0^{\mathrm{b}}$ & $41.0^{\mathrm{b}}$ & $60.0^{\mathrm{b}}$ \\
& Rimi PR & $50.5^{\mathrm{ab}}$ & $35.5^{\mathrm{ab}}$ & $50.0^{\mathrm{ab}}$ \\
& control & $64.0^{\mathrm{c}}$ & $53.5^{\mathrm{c}}$ & $71.5^{\mathrm{c}}$ \\
\hline \multirow{3}{*}{ number of shoots per } & NS Gricko & $/$ & $6^{\mathrm{a}}$ & $2^{\mathrm{a}}$ \\
plant & Dukat & $/$ & $6^{\mathrm{a}}$ & $2^{\mathrm{a}}$ \\
& Rimi PR & $/$ & $6^{\mathrm{a}}$ & $2^{\mathrm{a}}$ \\
& control & $/$ & $8^{\mathrm{b}}$ & $4^{\mathrm{a}}$
\end{tabular}

Letters in superscript denote differences between different intercrops within each legume; significance level $95 \%$.

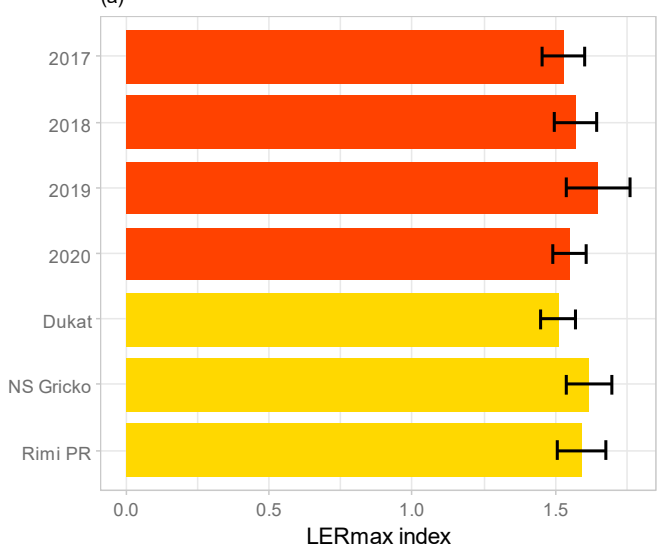

(b)

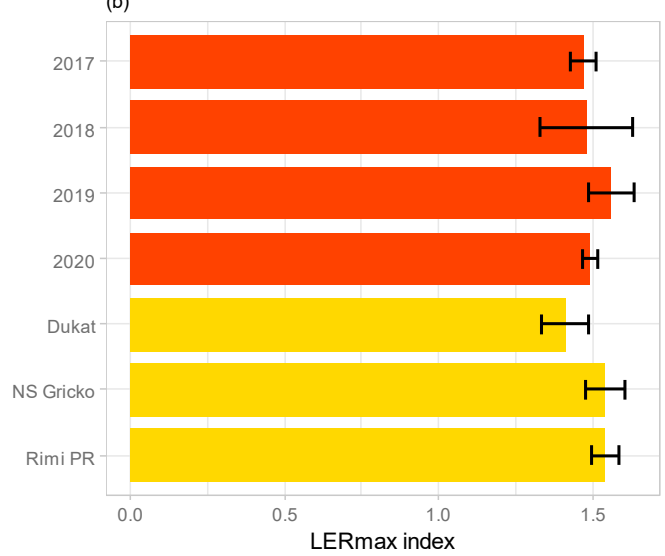

Figure 4. Adjusted land equivalent ratio (LERmax); (a) sunflower $\times$ red clover; $(\mathbf{b})$ sunflower $\times$ alfalfa intercropping. 


\section{Discussion}

In addition to the sustainability of the production system, it is very important to achieve the desired sunflower yield as it is the most important agronomic trait. Accelerated climate change characterized by extreme climatic hazards exposes the sunflower, a springsown and usually rain-fed crop, to the direct effect of heat stress and different drought scenarios, which can result in great yield losses and oil content decrease [26,27]. The abovementioned claims indicate variable and unpredictable conditions during the growing season, which was confirmed by four different vegetation seasons in which the experiment was performed. Figure 5 shows the yield data from our trial compared to the data from multi-environment trials for hybrid performance evaluation. At each trial year, the yields of sunflower intercropped with red clover and alfalfa were similar to the averages from multi-environment trials (same year).

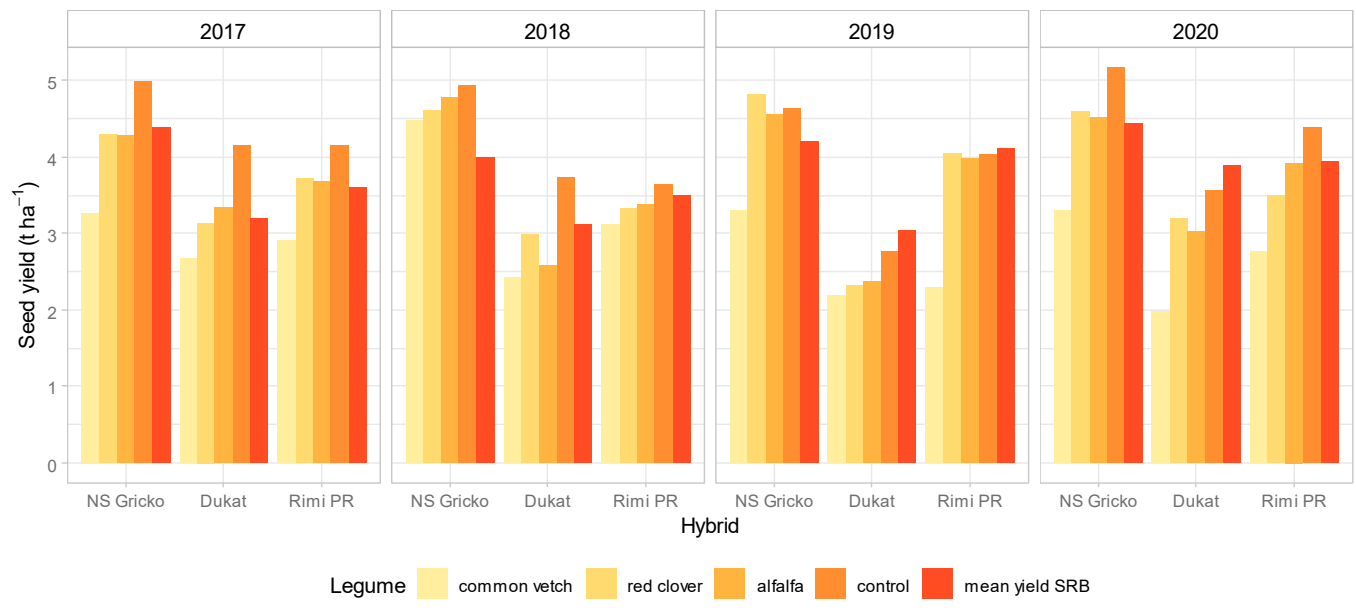

Figure 5. Sunflower seed yield in intercrops compared to average yield in multi-environment trials in Republic of Serbia agroecological conditions (average yield SRB-unpublished data from IFVCNS multi-environment trials).

From the producers' perspective, sunflower, as a cash crop, should achieve its yield potential when planted at the optimum planting density, which is the case in our research. Figure 5 shows that it is possible forthe sunflower to give similar yield as an average yield in our region when intercropped with legumes. Considering that perennial legumes give a more significant forage yield in the second year of establishment, they served as a soil cover, or living mulch in the first year of our trial. After sunflower harvesting in the first year, we already established a legume crop on the same plot, which will reach its full potential in the next vegetation period.

\subsection{Yield and Yield-Related Traits in Sunflower}

Morphological traits, such as head diameter, plant height, and total leaf area in flowering and bud phase had almost the same performance. A significant decrease in head diameter was observed in sunflowers with common vetch intercrops in all three hybrids, whereas intercropping sunflowers with red clover and alfalfa did not decrease this trait. Head diameter wasinfluenced by genotype and environmental conditions that occur during flowering and fertilization. The study previously conducted by Mrđa in the same environment (2015) [28] mentioned cultivation practices that result in a favourable number of plants per unit area, and precipitation arrangement and nutrients are significant for head diameter. Considering that yield is positively correlated with head diameter [29], it is necessary to choose thehybrids with the biggest head diameter, especially in the production of confectionary-type sunflowers. The growth dynamic and final height can interact with subsidiary legume crops.In addition to the fact that plant height is a genetically determined trait [30], it is also affected by the environment. In terms of plant height, hybrids from $1.5 \mathrm{~m}$ 
to $2 \mathrm{~m}$ are the most acceptable for hybrid production [31,32]. Additionally, shorter hybrids have the same yield potential as standard-height hybrids, but show better adaptability to different environmental conditions [31,33-35]. All the three hybrids examined in our study were significantly lowest when intercropped with common vetch, which could be considered positive. However, this combination also significantly reduced other agronomically important traits in sunflowers, which could be explained by the fact that the initial growth of vetch is somehow faster compared to alfalfa and red clover. Intercropping of hybrid NS Gricko with alfalfa significantly lowered plant height compared to sole cropping, but important traits as yield were not reduced, so we can conclude that this combination can result in a crop that is less susceptible to lodging and easier to combine, which is especially important for confectionary-type hybrids with robust plant architecture. The plant height in other combinations was the same as in sole cropping. The importance of the total leaf area in the development of seed yield results from the basic function of leaves, that is, photosynthesis, producing more than $90 \%$ of organic matter. This trait is very variable and depends on the genotype, as well as mineral nutrition, humidity, plant light, density of the assembly, sowing date, and so forth [36]. In his study, Balalić (2009) [37] stated that the application of various cultivation practices, which may include intercropping as the mode of production, can affect the size of the leaf area more than yield or other sunflower traits. In our study, the total leaf area was significantly lowered in all intercrops compared to the control. Seed yield was lower in interaction with common vetch in all three hybrids, and also in the Rimi PR $\times$ red clover interaction. The assumption is that intercropping of sunflowers with legumes can slow down sunflower growth to a certain extent, but only until the moment of complete root development (budding). In the later stages, there should be no competition for soil moisture. The interaction of all three hybrids with red clover and alfalfa was at the same level of significance, so we conclude that there is no difference in the influence of these two species on the leaf area.

Agronomically important traits of sunflower as a cash crop should be given special consideration in the first year. Considering the fact that sunflower oil content is lower in dry than in humid years, especially if the lack of moisture which determines the oil content occurs in the period from flowering to maturation [38,39], the microclimate created by legumes can be very important. The four-year period of the experiment was very different in terms of the weather conditions, but the oil content remained unchanged in all combinations, as well as in sole cropping. Seed yield is the main objective of sunflower production. It is related to many factors, such as sowing density, one thousand seed weight, the number of full seeds per head, head diameter, and cultivation practices during the vegetation period, so any decrease or increase in any of the factors will affect the yield. In our study, seed yield was affected by intercropping all hybrids with common vetch, as well as by intercropping Dukat with the other two legumes. Because Dukat is a shorter vegetation hybrid, this result was probably due to inter- and intraspecific competition for light, moisture, space, and nutrients in the first part of the vegetation period, which could not be compensated due to the short period of vegetation. NS Gricko and Rimi PR were not significantly affected by intercropping with alfalfa. NS Gricko is a confectionary type hybrid with the most robust plant architecture and a good competition ability, so intercropping with red clover did not significantly decrease its yield. Olowe andAdebimpe (2009) [40] also stated that average yields of the sunflower and soybean intercrops were similar to those of monocrop, probably because of enhanced productivity of individual plants under intercropping conditions. Kandel et al. (1997) [41] stated that hairy vetch sown at the same time as sunflowers reduced the number of full seeds per head compared with the control which is in accordance with our study. Since the number of full seeds per head is in direct correlation with yield [42] it was expected that this trait, as well as the yield of hybrid Dukat would be influenced by interactions with common vetch. Thousand seeds weight is a major yield component, and breeding for its increase leads to direct seed yield increase [42]. The fact that the interaction with legumes did not affect this trait is very important both for oil and for confectionary type hybrids. Significant positive correlation 
was found between SY and SYH which was to be expected because that SYH directly affects final yield per hectare.

\subsection{Biomass and Biomass Related Traits in Legumes}

In intercropping systems legumes tend to be beneficial for main crops because they bring high amounts of nitrogen into the soil and show positive effects on yield [43]. It is therefore highly likely that they contributed to the yields of sunflowers in our systems. Since red clover and alfalfa are perennial species, the characteristics of their traits are also important. Biomass, as the main outcome in the second year, is formed on the basis of performance from the year of establishment. Biomass of common vetch and red clover was at the same level of significance in sole crops and in intercrops with Rimi PR hybrid, as well as the biomass of alfalfa in interaction with NS Gricko, which results in the satisfactory biomass in the year of fodder exploitation, as established by other authors [44].

\subsection{Land Equivalent Ratio (LERmax)}

In the present additive intercropping model, sunflower and legumes were both intercropped at $100 \%$ of the optimal plant densities, resulting in a total of $200 \%$. It was, therefore, obvious that the pure stands, sown at the optimum (100\%) plant density for each crop, were significantly more productive in terms of seed yields and biomass compared to the evaluated intercropping treatments. These results are in agreement with the findings of Kandel et al. (1997) [41] who has reported higher yields for sole over intercropped sunflower and hairy vetch. However, the analysis of land use efficiency and yield gain revealed that the LERmax values for both sunflower $\times$ red clover and sunflower $\times$ alfalfa were higher than one, which indicated the advantage of intercropping over sole cropping of both crops. The maximum LER value (1.6) was obtained when hybrids NS Gricko and Rimi PR were intercropped with red clover indicating $60 \%$ yield gain over sole cropping. Yield increase achieved by intercropping, as confirmed by the high LERmax values, could be attributed to the complementary utilization of the above- and belowground resources and inputs for farming component crops. This intercropping model increased the overall resource use efficiency during the period of the growing season occupied by both crops.

\section{Conclusions}

Sunflower and legume intercropping has not been extensively analysed and this combination is rarely used in practice. Therefore, our study attempted to enhance sunflower intercropping management by encompassing sustainable practices and legume utilization. Based on the obtained results in intercropping systems, intercropping sunflower $\times$ alfalfa is the most appropriate combination. Since a thousand-seed weight is one of the most important confectionery-type trait, the fact that interaction with legumes did not affect this trait is very important. In addition to seed yield, oil content and yield are major important traits for oil-type hybrids. Oil content remained unchanged in all hybrids, all intercropping combinations, and in sole crops. The yield of NS Gricko and Rimi PR were statistically on the same level in sole cropping, while alfalfa biomass gave the best results when intercropped with NS Gricko. In addition, yields of sunflower intercropped with red clover and alfalfa were similar to the average values obtained from the multi-environment trials, which indicates that the system has great potential for transfer into practice. Longterm effects of the system can also be extremely important (though not examined in detail in this particular paper), especially in view of the general belief that intercropping results in more stable yields; further research in this direction is therefore needed. Research on the time and method of sowing will be the second phase of the experiment.

Author Contributions: Conceptualization, B.B. and S.Š.; methodology, S.Š. and N.H.; software, B.B. and D.S.; validation, B.B., S.Š. and N.H.; formal analysis, B.B., N.Ć. and M.R.; investigation, B.B.; resources, S.Š. and N.H.; data curation, D.S.; writing —original draft preparation, B.B.; writingreview and editing, S.S.., N.H. and M.R.; visualization, B.B. and N.Ć.; supervision, S.Š. and N.H. All authors have read and agreed to the published version of the manuscript. 
Funding: This research was supported by the Ministry of Education, Science and Technological Development of the Republic of Serbia, grant number: 451-03-9/2021-14/200032.

Institutional Review Board Statement: Not applicable.

Informed Consent Statement: Not applicable.

Data Availability Statement: Not applicable.

Acknowledgments: Authors want to thank Faculty of Agriculture, University of Novi Sad and Institute of Field and Vegetable Crops, Novi Sad for providing laboratory and field trial support.

Conflicts of Interest: The authors declare no conflict of interest.

\section{References}

1. Debaeke, P.; Casadebaig, P.; Flenet, F.; Langlade, N. Sunflower crop and climate change: Vulnerability, adaptation, and mitigation potential from case-studies in Europe. OCL Oilseeds Fats Crop. Lipids 2017, 24, D102. [CrossRef]

2. IPCC. Climate Change 2014: Synthesis Report. In Core Writing Team; Contribution of Working Groups I, II and III to the Fifth Assessment Report of the Intergovernmental Panel on Climate Change; Pachauri, R.K., Meyer, L.A., Eds.; IPCC: Geneva, Switzerland, 2014.

3. Stomph, T.; Dordas, C.; Baranger, A.; de Rijk, J.; Dong, B.; Evers, J.; Gu, C.; Li, L.; Simon, J.; Steen Jensen, E.; et al. Designing intercrops for high yield, yield stability and efficient use of resources: Are there principles? Adv. Agron. 2020, 160, 1-50. [CrossRef]

4. European Commission. Communication for the Commission to the European Parliament, the Council, the European Economic and Social Committee and the Committee of the Regions. EU Biodiversity Strategy for 2030. Bringing Nature Back into Our Lives. 2020. Available online: https:/ / eur-lex.europa.eu/legal-content/EN/TXT/?uri=CELEX:52020DC0380 (accessed on 21 April 2021).

5. Vandenncer, J.H. The Ecology of Intercropping; Cambridge University Press: Cambridge, UK, 1989; p. 231. Available online: https://www.cambridge.org/core/journals/experimental-agriculture/article/abs/ecology-of-intercropping-by-j-hvandermeer-cambridge-cambridge-university-press-1989-pp-237-3000/D053A24CEC50A9141A22CA758E7A2ADA (accessed on 21 April 2021).

6. Caviglia, O.P.; Sadras, V.O.; Andrade, F.H. Intensification of agriculture in the south-eastern Pampas: I. Capture and efficiency in the use of water and radiation in double-cropped wheat-soybean. Field Crops Res. 2004, 87, 117-129. [CrossRef]

7. Ren, W.; Hu, L.; Zhang, J.; Sun, C.; Tang, J.; Yuan, Y.; Chen, X. Can positive interactions between cultivated species help to sustain modern agriculture? Front. Ecol. Environ. 2014, 12, 507-514. [CrossRef]

8. Šeremešić, S.; Manojlović, M.; Ilin, Ž.; Vasić, M.; Varga-Gvozdanović, J.; Subašić, A.; Vojnov, B. Effect of intercropping on the morphological and nutritional properties of carrots and onions in organic agriculture. J. Process. Energy Agric. 2018, 22, 80-84. Available online: https:/ / scindeks-clanci.ceon.rs/data/pdf/1821-4487/2018/1821-44871802080S.pdf (accessed on 6 January 2021). [CrossRef]

9. Martin-Guay, M.O.; Paquetteb, A.; Duprasa, J.; Rivesta, D. The new Green Revolution: Sustainable intensification of agriculture by intercropping. Sci. Total Environ. 2018, 615, 767-772. [CrossRef] [PubMed]

10. Maitra, S.; Hossain, A.; Brestic, M.; Skalicky, M.; Ondrisik, P.; Gitari, H.; Brahmachari, K.; Shankar, T.; Bhadra, P.; Palai, J.B.; et al. Intercropping-A low input agricultural strategy for food and environmental security. Agronomy 2021, 11, 343. [CrossRef]

11. Rad, S.V.; Valadabadi, S.A.R.; Pouryousef, M.; Saifzadeh, S.; Zakrin, H.R.; Mastinu, A. Quantitative and qualitative evaluation of Sorghum bicolor L. under intercropping with legumes and different weed control methods. Horticulturae 2020, 6, 78. [CrossRef]

12. Federer, W.T. Statistical design and analysis for intercropping experiments: Volume 1: Two crops; Springer Science \& Business: Berlin/Heidelberg, Germany, 2012. [CrossRef]

13. Brooker, R.W.; Bennett, A.E.; Cong, W.F.; Daniell, T.J.; George, T.S.; Hallett, P.D.; Hawes, C.; Iannetta, P.P.M.; Jones, H.G.; Karley, J.K.; et al. Improving intercropping: A synthesis of research in agronomy, plant physiology and ecology. New Phytol. 2015, 206, 107-117. [CrossRef] [PubMed]

14. Hauggaard-Nielsen, H.; Gooding, M.; Ambus, P.; Corre-Hellou, G.; Crozat, Y.; Dahlmann, C.; Dibet, A.; von Fragstein, P.; Pristeri, A.; Monti, M.; et al. Pea-barley intercropping for efficient symbiotic N2-fixation, soil N acquisition and use of other nutrients in Europe an organic cropping systems. Field Crop. Res. 2009, 113, 64-71. [CrossRef]

15. Ugrenović, V.; Ugrinović, M. Organska proizvodnja i biodiverzitet. In Pokrovni Usevi_Ostvarenje Održivosti u Sistemima Ekološke Poljoprivrede; Ugrenović, V., Filipović, V., Eds.; Institut “Tamiš”: Pančevo, Srbija, 2014; pp. 1-15.

16. Iverson, A.L.; Marín, L.E.; Ennis, K.K.; Gonthier, D.J.; Connor Barrie, B.T.; Remfert, J.L.; Cardinale, B.J.; Perfecto, I. Do polycultures promote win-wins or trade-offs in agricultural ecosystem services? Ameta-analysis. J. Appl. Ecol. 2014, 51, 1593-1602. [CrossRef]

17. Bousselin, X.; Cassagne, N.; Baux, A.; Valantin-Morison, M.; Herrera, J.M.; Lorin, M.; Hédan, M.; Fustec, J. Interactions between plants and plant-soil in functionally complex mixtures including grass pea, faba bean and niger, intercropped with oilseed rape. Agronomy 2021, 11, 1493. [CrossRef]

18. de la Fuente, E.; Suárez, S.; Lenardis, A.; Poggio, S. Intercropping sunflower and soybean in intensive farming systems: Evaluating yield advantage and effect on weed and insect assemblages. NJAS—Wagening. J. Life Sci. 2014, 70-71, 47-52. [CrossRef] 
19. FAO—Food and Agriculture Organization of the United Nations. World Fertilizer Trends and Outlook to 2020. 2017. Available online: http:/ / www.fao.org/3/i6895e/i6895e.pdf (accessed on 12 December 2020).

20. Jensen, E.S.; Carlsson, G.; Hauggaard-Nielsen, H. Intercropping of grain legumes and cereals improves the use of soil N resources and reduces the requirement for synthetic fertilizer N: A global-scale analysis. Agron. Sustain. Dev. 2020, 40, 5. [CrossRef]

21. International Union of Soil Sciences (IUSS) Working Group WRB. World Reference Base for Soil Resources 2014, update 2015. In International Soil Classification System for Naming Soils and Creating Legends for Soil Maps; World Soil Resources Reports No. 106; FAO: Rome, Italy, 2015; Available online: http:/ / www.fao.org/3/i3794en/I3794en.pdf (accessed on 12 December 2020).

22. Granlund, M.; Zimmerman, D.C. Effect of drying conditions on oil contents of sunflower (Helianthus annuus L.) seed determined by wide-line Nuclear Magnetic Resonance (NMR). North Dak. Acad. Sci. Proc. 1975, 27, 128-132.

23. Willey, R.W. Intercropping-Its importance and research needs. I. Competition and yield advantages. Field Crop. Abstr. 1979, $32,1-10$.

24. SAS Institute. The SAS System for Windows; Release 9. 2; SAS Inst.: Cary, NC, USA, 2011.

25. IBM Corp. Released. IBM SPSS Statistics for Windows; Version 24.0; IBM Corp: Armonk, NY, USA, 2016.

26. Donatelli, M.; Srivastava, A.K.; Duveiller, G.; Niemeyer, S.; Fumagalli, D. Climate change impact and potential adaptation strategies under alternate realizations of climate scenarios for three major crops in Europe. Environ. Res. Lett. 2015, 10, e75005. Available online: https://iopscience.iop.org/article/10.1088/1748-9326/10/7/075005/pdf (accessed on 22 February 2021). [CrossRef]

27. Debaeke, P.; Casadebaig, P.; Langlade, N.B. New challenges for sunflower ideotyping in changing environments and more ecological cropping systems. OCL 2021, 28, 29. [CrossRef]

28. Mrđa, J. The Effect of Seed Quality on the Developmental Dynamics, Yield and Quality of Sunflower. Ph.D. Thesis, Faculty of Agriculture, University of Novi Sad, Novi Sad, Serbia, 2015. Available online: https://www.cris.uns.ac.rs/DownloadFileServlet/ Disertacija144611228383810.pdf?controlNumber=(BISIS)96075\&fileName=144611228383810.pdf\&id=4497\&licenseAccepted $=$ true (accessed on 8 November 2020).

29. Kholghi, M.; Bernousi, I.; Darvishzadeh, R.; Pirzad, A. Correlation and path-coefficient analysis of seed yield and yield related trait in Iranian confectionery sunflower populations. Afr. J. Biotechnol. 2011, 10, 13058-13063. Available online: https:/ / www.ajol.info/index.php/ajb/article/view/96515/85837 (accessed on 8 November 2020).

30. Radanović, A.; Miladinović, D.; Cvejić, S.; Jocković, M.; Jocić, S. Sunflower genetics from ancestors to modern hybrids-A review. Genes 2018, 9, 528. [CrossRef] [PubMed]

31. Škorić, D.; Mihaljčević, M.; Jocić, S.; Marinković, R.; Dozet, B.; Atlagić, J.; Hladni, N. The latest achievements in sunflower breeding. In Proceedings of the 37. Savetovanje Proizvodnja i Prerada Uljarica, Budva, Yugoslavia, 27-31 May 1996; Tehnološki Fakultet Novi Sad: Novi Sad, Srbija, 1996.

32. Vratarić, M.; Sudarić, A. Oplemenjivanje i Genetika Suncokreta. U Suncokret (Helianthus annuus L.); Poljoprivredni Institut Osijek: Osjek, Hrvatska, 2004; pp. 69-162.

33. Miller, J.F.; Hammond, J.J. Inheritance of reduced height in sunflower. Euphytica 1991, 53, 131-136. [CrossRef]

34. Schneiter, A.A. Production of semi dwarf and dwarf sunflower in the northern Great Plains of the United States. Field Crop. Res. 1992, 30, 391-401. [CrossRef]

35. Velasco, L.; Pérez-Vich, B.; Muñoz-Ruz, J.; Fernández-Martínez, J.M.; Friedt, W. Inheritance of reduced plant height in the sunflower line Dw89. Plant Breed. 2003, 122, 441-443. [CrossRef]

36. Beg, A.; Pourdad, S.S.; Pala, M.; Oweis, T. Effect of supplementary irrigation and variety on yield and some agronomic characters of sunflower growing under rainfed conditions in northern Syria. Helia 2007, 30, 87-98. [CrossRef]

37. Balalić, I. Multivariate Analysis of Interaction between Hybrids and Planting Dates for Oil Content, Yield and Yield Components in Sunflower. Ph.D. Thesis, Faculty of Agriculture, University of Novi Sad, Novi Sad, Serbia, 2009.

38. Marinković, R.; Dozet, B.; Vasić, D. Sunflower Breeding; Monography, Školska Knjiga: Novi Sad, Serbia, 2003.

39. Gontcharov, S.; Zaharova, M. Vegetation period and hybrid sunflower productivity in breeding for earliness. In Proceedings of the 17th International Sunflower Conference, Cordoba, Spain, 8-12 June 2008; pp. 531-533. Available online: https: / www. isasunflower.org/fileadmin/documents/aaProceedings/17thISC_CordobaVol2/531sergey.pdf (accessed on 6 January 2021).

40. Olowe, V.I.O.; Adebimpe, O.A. Intercropping sunflower with soya beans enhances total crop productivity. Biol. Agric. Hortic. 2009, 26, 365-377. [CrossRef]

41. Kandel, H.J.; Schneiter, A.A.; Johnson, B.L. Intercropping legumes in to sunflower at different growth stages. Crop Sci. 1997, 37, 1532-1537. [CrossRef]

42. Hladni, N.; Jocić, S.; Miklič, V.; Miladinović, D.; Zorić, M. Interrelationship between 1000 seed weight with other quantitative traits in confectionary sunflower. Ekin J. Crop Breed. Genet. 2016, 2, 51-56. Available online: https://dergipark.org.tr/en/download/ article-file/211599 (accessed on 8 November 2020).

43. Rosner, K.; Bodner, G.; Hage-Ahmed, K.; Steinkellner, S. Long-term soil tillage and cover cropping affected arbuscular mycorrhizal fungi, nutrient concentrations, and yield in sunflower. Agron. J. 2018, 110, 2664-2672. [CrossRef]

44. Dowling, A.; Sadras, V.O.; Roberts, P.; Doolette, A.; Zhou, Y.; Denton, M.D. Legume-oilseed intercropping in mechanised broad acre agriculture-A review. Field Crop. Res. 2021, 260, 107980. [CrossRef] 